\title{
Surgical Management of Lymphoma in a Dog- A Case Report
}

\author{
Rakesh Kumar', Gaurav Kumar ${ }^{2}$, Rajeev Kumar $^{3}$ and Vinay Yadav \\ ${ }^{1}$ Veterinary Surgeon, GVH Dublana (Mahender Garh), Department of Animal Husbandry and \\ Dairying, Haryana123001, India \\ ${ }^{2}$ Department of Veterinary Surgery and Radiology, LUVAS, Hisar 125004 \\ ${ }^{3}$ Veterinary Surgeon, GVH Deroli Ahir (Mahender Garh), Department of Animal Husbandry \\ and Dairying, Haryana 123001, India \\ ${ }^{2}$ Department of Veterinary Gynaecology and Obstetrics, LUVAS, Hisar 125004 \\ *Corresponding author
}

A B S T R A C T

\begin{tabular}{|c|c|}
\hline Keywords & \\
\hline $\begin{array}{l}\text { Surgical } \\
\text { Management, } \\
\text { Lymphoma, } \\
\text { Histopathological } \\
\text { examination }\end{array}$ & \multirow{3}{*}{$\begin{array}{l}\text { A male Dog, breed German Shepherd age } 3 y r s \text { approximate was presented } \\
\text { with the history of anorexia, weight loss, muscular weakness, depression, } \\
\text { polydipsia, polyuria and bilateral peripheral lymphadenopathy at the } \\
\text { hospital. The blood picture of the animal showed normal blood counts as } \\
\text { well as normal LFT and KFT. On histopathological examination of the } \\
\text { tumorous growth extracted from the lymph node clearly showed Non- } \\
\text { Hodgkin's Lymphoma that was surgically removed successfully. }\end{array}$} \\
\hline Article Info & \\
\hline $\begin{array}{l}\text { Accepted: } \\
\text { 26 July } 2018 \\
\text { Available Online: } \\
10 \text { August } 2018\end{array}$ & \\
\hline
\end{tabular}

\section{Introduction}

Lymphoma is the most common hematopoietic neoplasm in the $\operatorname{dogs}$ representing 7-9 percent of all malignant neoplasms (Hammer and Couto, 1991). The annual incidence has been estimated at 24 per 100000 dogs (Dorn et al., 1970), although a lower incidence has been reported in other surveys (Back-green, 1965; Parodi et al., 1968). Dogs are often asymptomatic, but 20-
$40 \%$ of dogs will have anorexia, lethargy, fever weight loss, vomiting, diarrhea and melena (Vail et al., 2001). The clinical signs of canine lymphoma usually reflect the anatomical site affected, in this particular case there is excessive enlargement of pre-scapular lymph nodes, weight loss, anorexia, depression, polydipsia and polyuria. The main purpose of this study was to report on this type of canine lymphoma which is rare in every day practice. 


\section{History and Observations}

A 3 years German Shepherd male Dogwas presented to the Government Veterinary Hospital, Dublana Distt Mahender Garh, Haryana with the history of anorexia, weight loss, muscular weakness, depression, polydipsia, polyuria etc. Body temperature was subnormal $\left(99^{\circ} \mathrm{F}\right)$. On physical examination both the pre-scapular lymph nodes were enlarged extensively. On aseptic lymph node centesis, blood mixed aspirate was able to be collected with a sixteen-gauze sterile needle and syringe. Complete blood examination of the dog was conducted along with Liver function tests (LFT) and Kidney function test (KFT) and complete Urine analysis to assess the changes and physiological status of different visceral organs.

\section{Treatment and Discussion}

The complete blood count showed lymphocytosis but LFT as well as complete Urinalysis showed normal report however slight increase in blood urea levels was observed (Table 1). History, site, subcutaneous location, round shape of the growths made it suspect as benign growth. It indicated that the tumor is non-malignant in nature or metastasis is not happened yet i.e. early detection of the tumor.

Table.1 Hemato-biochemical picture of the patient

\begin{tabular}{|c|c|c|}
\hline Parameters & Obtained value & Normal range \\
\hline 1) TLC & 12,600/ cu.mm. & 5100-14100/cu.mm. \\
\hline 2) Neutrophils & $74 \%$ & $58-85 \%$ \\
\hline 3) Lymphocytes & $22 \%$ & $8-21 \%$ \\
\hline 4) Eosinophils & $4 \%$ & $0-9 \%$ \\
\hline 5) Serum bilirubin & $0.6 \mathrm{mg} / \mathrm{dL}$ & $0-0.3 \mathrm{mg} / \mathrm{dL}$ \\
\hline 6) Serum creatinine & $1.2 \mathrm{mg} / \mathrm{dL}$ & $0.5-1.7 \mathrm{mg} / \mathrm{dL}$ \\
\hline 7) Blood urea nitrogen & $20 \mathrm{mg} / \mathrm{dL}$ & $8-28 \mathrm{mg} / \mathrm{dL}$ \\
\hline 8) ALT & $23 \mathrm{U} / \mathrm{L}$ & 10-109U/L \\
\hline 9) $\mathrm{AST}$ & $31 \mathrm{U} / \mathrm{L}$ & 13-15U/L \\
\hline 10) ESR & $5 \mathrm{~mm} / \mathrm{hr}$ & $0-6 \mathrm{~mm} / \mathrm{hr}$ \\
\hline
\end{tabular}

Many types of treatment have been proposed for canine Non-Hodgkin Lymphoma but the most commonly used is chemotherapy. Single agent protocols were initially used (i.e. Doxorubicin, Cyclophosphamide), but nowadays multiple agent chemotherapy is the most common approach to NHL and canine Non-Hodgkin Lymphoma. Currently, response to chemotherapy in multicentric Bcell canine Non-Hodgkin Lymphoma is about $80 \%$. Unfortunately, it is not curative but induces remission with a good quality of life for dogs. The median survival in B-cell canine Non-Hodgkin Lymphoma in treated dogs is about 12 months (Gavazza et al., 2013). So, surgical excision of the growths was opted for the treatment. Both Prescapular lymph nodes of the dog were surgically removed aseptically under general anesthesia using Inj. xylazine hydrochloride as sedative@ $0.5 \mathrm{mg}$ per kg bodyweight intramuscularly. Anesthesia was maintained by ketamine@ @mg per kg body weight and midazolam @0.25mg per kg body weight combination as per dosage formulation given by Fossum (2007).

A Part of the growth was sent for histopathological examination for the evidence of any type of tumorous growth. However, the other reports were normal and there was no evidence of malignancy. The 
owner was advised to keep the dog on Inj. Ceftriaxone and Tazobactum combination@ 20mg per kg bodyweight intramuscularly, Inj. Meloxicam @ 0.3mg per kg bodyweight intramuscularly, Inj. Mecovet XL $2 \mathrm{ml}$ intramuscularly, Inj. Vit-C $2 \mathrm{ml}$ intramuscularly, all these for 5 Days and Anti-Septic Dressing Daily for a faster recovery. No complication or infection was found post-operatively. Sutures were removed after 8 days and the dog was apparently healthy. Surgically resected mass was incised and the cut surface grossly appeared greyish brown and soft in nature. Histopathological study of the growth extracted clearly revealed the presence of non-Hodgkin's lymphoma (diffuse, large cell).

The haemogram in canine lymphoma is not usually diagnostic (Madewell and Theilen, 1987). Neutrophilic leukocytosis and lymphocytosis are common findings (Couto, 1985). The clinical staging of these canine lymphoma cases based on WHO criteria (Owen, 1980) could fit in stage-I. Nowadays, the ultimate therapy for both humans and dogs is vaccine treatment. In recent times the genetic vaccine Targeting Dog Telomerase (dTERT), based on Ad/DNA-EP technology (Adenovirus and DNA electroporation), has been found to induce strong immune responses and increased overall survival of dogs affected by B-cell lymphoma in comparison with controls when combined with a COP (corticosteroids, vincristine, and cyclophosphamide) chemotherapy regimen. No adverse effects that might be attributed to treatment have been observed in any patient. A dTERT-specific immune response has been induced in almost all the treated animals (Gavazza et al., 2013).

\section{References}

Backgreen, A.W. (1985). Lymphatic Leukosis in Dogs. Acta Veterinaria Scandinavica, 6: (Supplement), 1.

Couto, C.G. (1985). Canine Lymphomas: Something old, Something New. Compendium of Continuing Education 7: 291-98.

Fossum, T.W. (2007) Small Animal Surgery, $3^{\text {rd }}$ Edn, Mosby Elsevier, p 307-10.

Gavazza, A., Bocci, G. and Giorgi, G. (2013). Treatment of canine lymphoma as a model for humans. Journal of Clinical and Experimental Pharmacology. 3:e120.

Hammar, S.A. and Couto, C.G. (1991) Lymphadenopathy and splenomegaly. In: small Animal Medicine. Ed D.A. Allen, J.B. Lippincott, Philadelphia. Pp 156.

Madewell, R.B. and Theilen, H.G. (1987). Tumors of the Urogenital tract. In: Veterinary Cancer Medicine. $2^{\text {nd }}$ edn. Lea and Febiger, Philadelphia. Pp. 567-600.

Owen, L. (1980). WHO Clinical Staging. Geneva, World Health Organization, VPH/CMO/20. p 47.

Parodi, A., Wyers, M. and Paris, J. (1986). Incidence of canine lymphoid leucosis. Age, breed and sex distribution, results of necroscopic survey. Bibliotheca Haematologica.30: 263-267.

Vail, D.M., MacEwen, E.G. and Young, K.M.(2001). Canine lymphoma and lymphoid leukemias. In: Withrow, S.J. and MacEwen, E.G. (eds): Small Animal Clinical Oncology (ed 3). New York, Saunders, pp. 558-590.

\section{How to cite this article:}

Rakesh Kumar, Gaurav Kumar, Rajeev Kumar and Vinay Yadav. 2018. Surgical Management of Lymphoma in a Dog- A Case Report. Int.J.Curr.Microbiol.App.Sci. 7(08): 4419-4421. doi: https://doi.org/10.20546/ijcmas.2018.708.465 